\title{
'A STUDY ON TREND ANALYSIS OF MARUTI SUZUKI INDIA LIMITED’
}

\author{
M. YASODHA ${ }^{1}$, G. SHARMILA ${ }^{2}$, A. S. SUBASHREE ${ }^{3} \&$ K. YAMUNADEVI ${ }^{4}$ \\ ${ }^{1}$ Assistant Professor, PSGR Krishnammal College for Women, \\ Coimbatore, Tamil Nadu, India \\ 2, 3, ${ }^{2}$ rofessional Accounting, PSGR Krishnammal College for Women, \\ Coimbatore, Tamil Nadu, India
}

\begin{abstract}
The automobile industry in India is one of the leading markets in the world. This industry is one of the fastest and largest growing industries in the world. In India, Maruti Suzuki India Limited is one of the largest automobile industries but is currently experiencing flat growth rates. The present study deals with the Trend Analysis with special reference to Maruti Suzuki India Limited in relation to the cost of goods sold and sales. Every possible effort has been made to examine the increasing or decreasing Trend of the company through various trend techniques of accounting. On the basis of conclusion drawn from the study, some useful suggestions has been given at the end of the study.

KEYWORDS: Trend Analysis, Maruti Suzuki \& Cost of Goods Sold
\end{abstract}

Received: Jan 30, 2019; Accepted: Feb 19, 2019; Published: Mar 07, 2019; Paper Id.: IJECRJUN20193

\section{INTRODUCTION}

Trend Analysis

Trend analysis is a tool used in the analysis of future predictions with regards to the future stock price movements based on the recently observed trend data. Trend analysis is regarded as the idea provided based on the happenings of future with relation to the past assumptions. There are three main types of trends: short-, intermediate- and long-term.

\section{Statement of the Problem}

Maruti Suzuki, the largest automobile represents an major service contribution part of Indian economy. The current scenario of automobile industry has not been constant, there are various barriers which has let to variations in the level of profits. The company has been facing due to their performance nature, the share price has been falling which in turn reduce the wealth of the shareholders.

\section{Objective of the Study}

- To study the past growth or decline of the series by eliminating short term and long term oscillations and irregular movements.

- With the help of trend curve the predictions are to be made in relation to forecast future trends.

\section{Research Methodology}

Research methodology refers to data collection and attempt to provide a pattern or trend in the information. Trend analysis allows plotting aggregated response over time, trend analysis is the kind of research 
methodology used.

\section{Tools and Techniques}

There are two methods of measuring trend analysis and they are

- By Graphical Method

- By Least squares method

\section{Limitation of the Study}

The limitations of the study are

- The trend analysis approach cannot provide accurate measures

- When the price level is not constant and when the accounts are not being made with consistent basis year after year then, it leads to unfavourable effect.

\section{REVIEW OF LITERATURE}

The ESRC Centre for Business Research (2004) ${ }^{1}$, in their study examines patterns and trends in motor vehicles using the data based on 23.1 million vehicles registered in the UK between 1992 and 2002. In their article it has absorbed some suggestions for corporate differences in propensity to recall and the differences between the manufacturer and their needs are further to be investigated taking into account the differences in model range, production volumes and the manufacturing design practices in order to establish the root causes for the concerning trend.

Kamrul Ahsan $(\mathbf{2 0 1 3})^{2}$, in his study showed the statistical analysis which relates to significant negative correlations between car model year and recalls frequency. It examines root causes and avoids the mishap of car recalls. This study states the investing issue and evaluates the performance for the beneficiary. This research overall provides insights of current car recalls and related issues.

\section{Company History}

Maruti Suzuki India Limited, formerly known as Maruti Udyog Limited, is an automobile manufacturer in India. It is a 56.21\% owned subsidiary of the Japanese car and motorcycle manufacturer Suzuki Motor Corporation. As of July 2018, it had a market share of 53\% of the Indian passenger car market Maruti Suzuki manufactures and sells popular cars such as the Ciaz, Ertiga, Wagon R, Alto K10, Swift, Celerio, Swift Dzire, Baleno and Baleno RS, Omni, Alto 800, Eeco, Ignis, S-Cross. The company is headquartered in New Delhi. In May 2015, the company produced its fifteen millionth vehicles in India, a Swift Dzire. Maruti was established in February 1981 with production starting in 1983 with the Maruti 800, based on the Suzuki Altokei car. As of May 2007, the Government of India, through the Ministry of Disinvestment, sold its complete share to Indian financial institutions and no longer has any stake in Maruti Udyog.

\section{Equity Structure of Maruti}

\section{$54.21 \%$ is MARUTI SUZUKI CORPORATION}

45.79\% is OTHERS (Financial institutions mutual funds, banks, public etc.) 


\section{Company's Strength}

Maruti Suzuki is recently being rated as the 4th most reputed automobile company in the world. This has happened because of the contribution of all the stakeholders of Maruti.

\section{Trend Analysis of Maruti Suzuki}

The following table shows the calculation of trend analysis

Table 1

\begin{tabular}{|l|c|c|c|c|c|c|c|c|}
\hline FACTORS & $\mathbf{2 0 1 1}$ & $\mathbf{2 0 1 2}$ & $\mathbf{2 0 1 3}$ & $\mathbf{2 0 1 4}$ & $\mathbf{2 0 1 5}$ & $\mathbf{2 0 1 6}$ & $\mathbf{2 0 1 7}$ & $\mathbf{2 0 1 8}$ \\
\hline Sales & 37040 & 35587 & 43567 & 43700 & 49970 & 57538 & 68034 & 79762 \\
\hline Sales Growth & - & 0.96 & 1.22 & 1.002 & 1.143 & 1.152 & 1.182 & 1.172384 \\
\hline Cogs & 33035 & 32205 & 39335 & 38586 & 43713 & 48646 & 58063 & 67660 \\
\hline $\begin{array}{l}\text { Cogs as a \% } \\
\text { of Sales }\end{array}$ & 89.18737 & 90.49653 & 90.28623 & 88.29748 & 87.47849 & 84.54587 & 85.34409 & 84.82736 \\
\hline $\begin{array}{l}\text { Operating } \\
\text { Income }\end{array}$ & 3638.5 & 2513 & 4229.6 & 5095 & 6712 & 8884 & 10351 & 12061 \\
\hline $\begin{array}{l}\text { Operating } \\
\text { Margin }\end{array}$ & 0.098232 & 0.070616 & 0.097083 & 0.11659 & 0.134321 & 0.154402 & 0.152145 & 0.151212 \\
\hline Employee & 8900 & 9413 & 9450 & 9711 & 9745 & 9777 & 9870 & 10000 \\
\hline $\begin{array}{l}\text { Revenue Per } \\
\text { Employee }\end{array}$ & 4.161798 & 3.780623 & 4.610265 & 4.500051 & 5.127758 & 5.885036 & 6.893009 & 7.9762 \\
\hline Net PPE & 0.40882 & 0.266971 & 0.447577 & 0.524663 & 0.688763 & 0.908663 & 1.048734 & 1.2061 \\
\hline $\begin{array}{l}\text { Accounts } \\
\text { Receivable }\end{array}$ & 1461.8 & 937.6 & 1469.9 & 1413.7 & 1069.8 & 1322.2 & 1199.2132 & 1461.8 \\
\hline Inventory & 3160.8 & 1796.5 & 1840.7 & 1705.9 & 2615 & 3132.1 & 3262.2 & 3160.8 \\
\hline
\end{tabular}

Source: Secondary data

The above trend table has shown that the sales of the company have decreased from $22.4 \%$ in 2013 to $17.28 \%$ in 2018 in relation with the sales growth. The cost of goods sold also decreased from $90.4 \%$ in 2012 to $84.82 \%$ in 2018 whereas the cost of goods sold in relation with the percent of sales has also shown a decline. Operating income trends positively so the operating margin derived from the operating income trended positively from $9.8 \%$ to $15.12 \%$.

There has been an increment level in the net PPE and asset utilization and in turn. There is an increase in the number of employees and revenue from employees.

\section{Methods under Trend Analysis on Basis of Which Problems are Studied}

Following problems are found during the study of trend analysis of Maruti Suzuki India Limited (MSIL)

- Cost of goods sold has been increased from 2011 to 2018 i.e., the expenses incurred for the production of items has increased during this particular period of time.

- The sales of the company have decreased from $22.4 \%$ in 2013 to $17.28 \%$ in 2018 in relation with the sales growth. Methods under TREND ANALYSIS on the basis of which problems are studied

- By Graphical Method

- By Least Squares Method 


\section{By Graphical Method}

The simplest method used for comparing data sets between two or more variables. In this method the results can be readily interpreted and derived.

\section{Trend Analysis of Cogs under Graphical Method}

Table 2

\begin{tabular}{|c|c|}
\hline YEAR & COGS \\
\hline 2011 & 33035 \\
\hline 2012 & 33205 \\
\hline 2013 & 39335 \\
\hline 2014 & 38568 \\
\hline 2015 & 43713 \\
\hline 2016 & 48646 \\
\hline 2017 & 58063 \\
\hline 2018 & 67701 \\
\hline
\end{tabular}

Source: Secondary data

\section{Trend Showing Cost of Goods Sold}

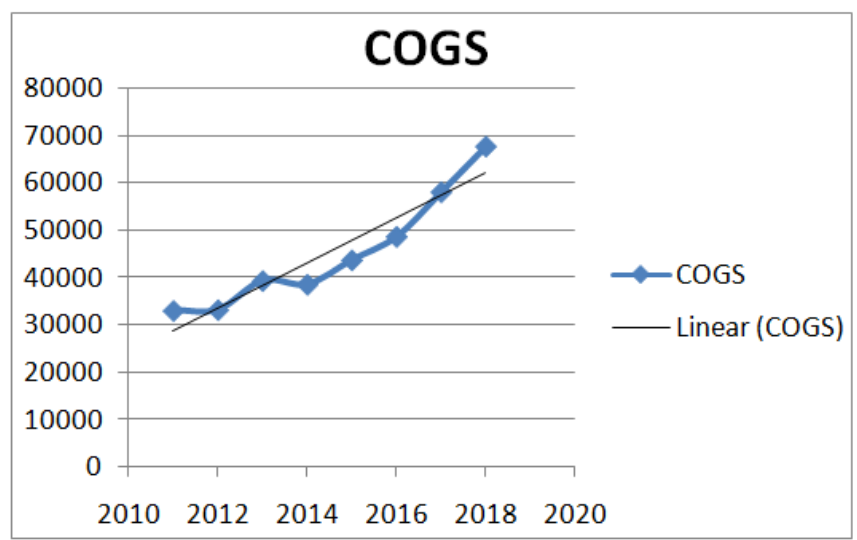

Figure 1

The above table and the graph, interpret the cost of goods sold datasets side by side, this trend readily results in the interpret. This has shown the level of comparison between the functional linear line and the feasible region on the graph. The prediction has been made from the year 2011-2018.

\section{Trend Analysis of Gross Profit Using Graphical Method}

The following table shows the gross profit under Graphical method

Table 3

\begin{tabular}{|c|c|}
\hline Year & GP \\
\hline 2011 & 4146.66 \\
\hline 2012 & 3339.75 \\
\hline 2013 & 5042.5 \\
\hline 2014 & 5918.18 \\
\hline 2015 & 7544.5 \\
\hline 2016 & 10345.47 \\
\hline 2017 & 12632.8 \\
\hline 2018 & 14107 \\
\hline
\end{tabular}

Source: Secondary data 
The Gross Profit of the company keeps on increasing year by year. An increased gross profit margin is important for a business because companies can use the money from the gross profit to expand. A small gross profit margin means a company has very little money to do anything except keep making its products at the same level.

\section{Trend Showing Gross Profit}

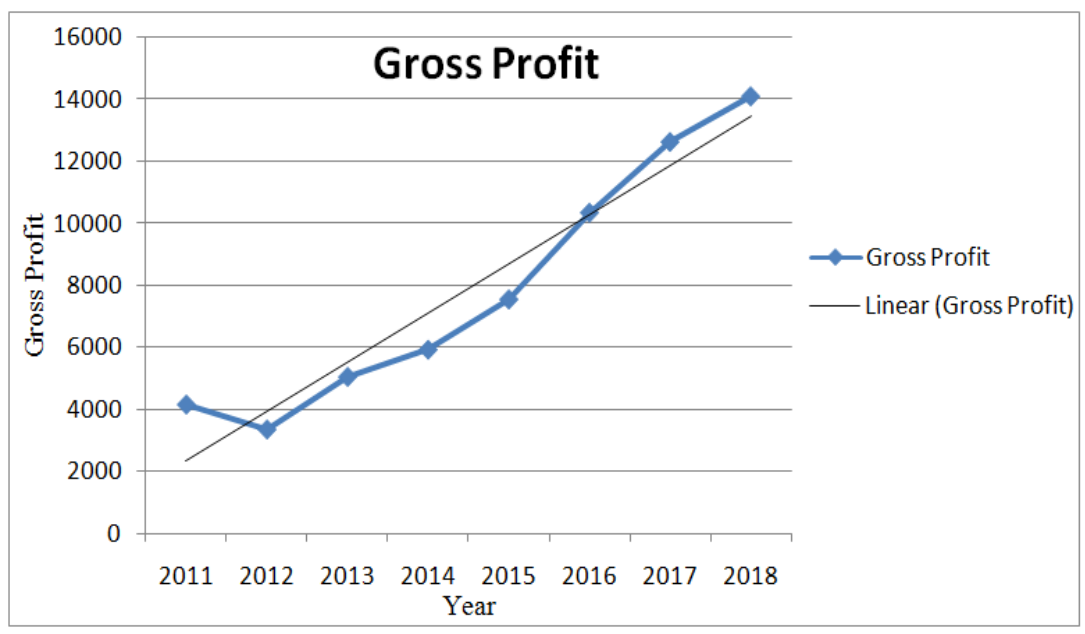

Figure 2

The above table and the graph, interpret the cost of goods sold datasets side by side, this trend readily results in the interpret. This has shown the level of comparison between the functional linear line and the feasible region on the graph. The prediction has been made from the year 2011-2018.

\section{Method of Least Squares}

Method of Least Squares commonly uses in regression analysis. This method deals with two and more sets, it also helps to find the line of best fit from the available sets, in such a manner that the following two conditions are satisfied

- $\quad \Sigma(\mathrm{Y}-\mathrm{Yc})=0$ i.e., the sum of deviations of the actual values of $\mathrm{Y}$ and the computed values of $\mathrm{Y}$ is zero.

- $\quad \Sigma(\mathrm{Y}-\mathrm{Yc})=2$ is least i.e., the sum of the squares of the deviations of the actual and computed values is least from this line and hence the name method of least squares.

\section{Trend Analysis of Cogs Using Least Squares Method}

Table 4

\begin{tabular}{|c|c|c|c|c|c|}
\hline Year & COGS(Y) & $\mathbf{X}$ & $\mathbf{X Y}$ & $\mathbf{X}^{\mathbf{2}}$ & $\mathbf{Y}_{\mathbf{C}}$ \\
\hline 2011 & 33035 & -3 & -99105 & 9 & 21461.5 \\
\hline 2012 & 33205 & -2 & -66410 & 4 & 29402 \\
\hline 2013 & 39335 & -1 & -39335 & 1 & 37342.6 \\
\hline 2014 & 38568 & 0 & 0 & 0 & 45283.25 \\
\hline 2015 & 43713 & 1 & 43713 & 1 & 53223 \\
\hline 2016 & 48646 & 2 & 97292 & 4 & 61164 \\
\hline 2017 & 58063 & 3 & 174189 & 9 & 69105 \\
\hline 2018 & 67701 & 4 & 270804 & 16 & 77045.5 \\
\hline $\mathrm{N}=8$ & EY=362266 & EXY=381148 & EX $^{2}=48$ & \\
\hline
\end{tabular}

Source: Secondary data 
Here arithmetic mean $=16116 / 8$

$$
=2015
$$

$$
\begin{aligned}
\mathrm{Y}_{\mathrm{C}} & =\mathrm{A}+\mathrm{BX} \\
\mathrm{A} & =\mathrm{EY} / \mathrm{N} \\
& =362266 / 8 \\
& =4528 \\
\mathrm{~B} & =\mathrm{EXY} / \mathrm{E} \mathrm{X}^{2} \\
& =381148 / 48 \\
& =794
\end{aligned}
$$

\section{Linear Trend by Method of Least Square}

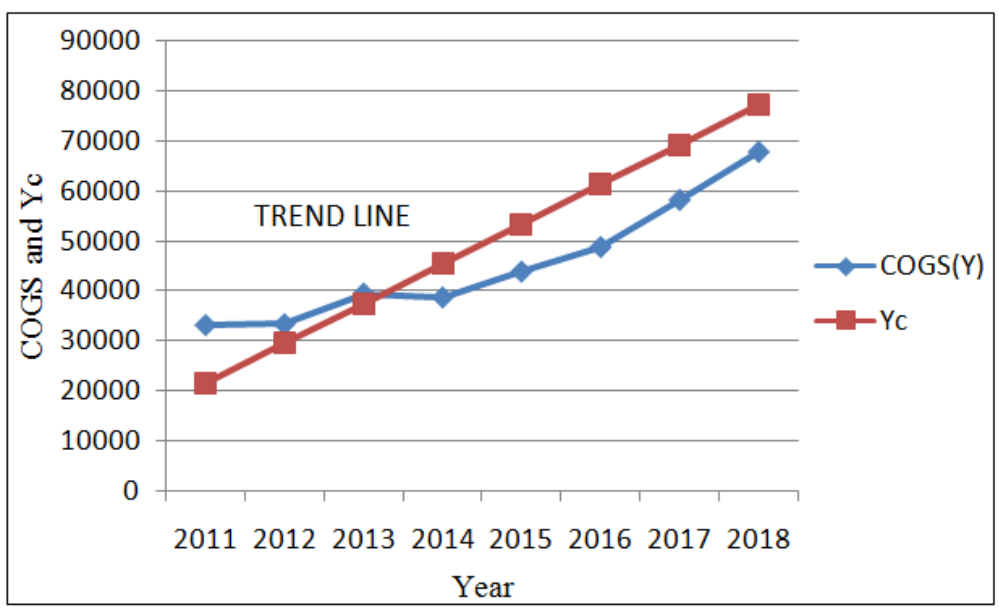

Figure 3

\section{Findings}

- As per the trend analysis made on Maruthi Suzuki India Limited it has been found that the sales and sales growth are in an inverse relationship due to competitive intensity, hike in the price level, less export sales and various other factors.

- The cost of goods sold and increasing sales growth are found to be inter-related with concern to the re-evaluating purchasing activity.

\section{SUGGESTIONS}

The future predictions can be made by trend analysis data has provided in this study, by keeping it as the base following suggestions can be done to increase the sales growth

- Create a separate culture of quality to withstand in the market

- Connections can be made with supply chain to keep updated about the happenings

- Apart from the inspection report the demand has to be more 


\section{CONCLUSIONS}

The study is aimed to analyse the trend of Maruti Suzuki India Limited for the period from almost 2011-2018 with the help of four tools. The study can be concluded by saying that the cost of goods sold can be reduced and also the sales growth must be increased in order to improve the position of the company by adopting certain measures that have been suggested.

\section{REFERENCES}

1. ESRC Centre for Business Research (2004), Hilary Bates, Matthias Holweg, Nick Oliver, Michael Lewis, 'Motors Vehicle Recalls: Trends Patterns and Emerging Issues', University Of Cambridge and Working Paper No. 295, PP. 1-17.

2. Kamrul Ahsan (2013), 'Trend Analysis of Car Recalls: Evidence From The US Market', International Journal of Managing Value And Supply Chains [IJMVSC], Volume-4, No-4 and PP.1-16.

3. Yusri, Yusniyati., \& Yee, K. (2015), Malaysian Taxpayers' Perception towards the Implementation of Goods and Service Tax (GST). International Journal of Economics, Commerce and Research, 1-8.

4. investopedia.com

5. wikipedia.org

6. marutisuzuki.com

7. fundsindia.com

8. Scribd.com

9. researchgate.net 
